\title{
The Design of Stereotype and the Image
}

\author{
Mark Roxburgh and Elena Caratti
}

\begin{abstract}
Our everyday life is influenced by an overproduction of images and by an iconogenic surplus that is connected to the proliferation of media. These contribute to both the quality and quan-tity of communication, but simultaneously amplify the knowledge gap between an audience that is able to critically process messages and another that is affected uncritically by prejudices and stereotypes. Bellino argues for a critical media education to address this gap by encourag-ing the development of students' critical thinking and social awareness. In this article we will discuss the results of a research-driven design project in which visual communication design students engaged with theories of cultural stereotypes and critiqued the role of media in their perpetuation. We adopted Kolb's model of experiential learning as recent published research demonstrates that art and design students have difficulties in conventional academic approaches to learning theory. In this regard students learned theories of stereotype through doing and making and embodied this learning in their critical project outcomes.
\end{abstract}

\section{KEYWORDS}

media education, design education, experiential learning, design practice and theory, critical design practice

\section{Introduction}

It is a cliché to say we live in an image-saturated world and it is self-evident that visual communicators are a party to this phenomenon. Yet in spite of this 'all-pervasive image-making' Mitchell $(1995,13)$ argues that 'we still do not know exactly what pictures are, what their relation to language is, how they operate on observers and on the world, how their history is to be understood, and what is to be done with or about them'. Visual communicators play a central role in shaping the landscape of visual images that we encounter on a daily basis, acting as cultural mediators between the organisations and clients they work for, and with, and the audience they seek to engage. Consequently they exercise enormous ideological power in shaping people's perception of reality. It is our view therefore that any ethical programme of study in visual communication design should require students to develop a critical attitude towards their practice and an awareness of the ideological power that they wield, for it has real consequences. This necessitates a broader engagement with cultural and critical theories. However, there is substantial literature that demonstrates that the position of theory in art and design schools has been problematic as it has generally been taught in a manner that privileges reading, analytic thinking and writing, whereas art and design students tend to learn by observing, using intuitive thinking and making. With that in mind we developed the content of a one-week intensive workshop, 'The Experience of Stereotype' in the MA in Communication Design at the Design School of the Politecnico di Milano, in a way that

\footnotetext{
This is the peer reviewed version of the following article: Roxburgh M., Caratti E. "The Design of Stereotype and the Image" (INTERNATIONAL JOURNAL OF ART \& DESIGN EDUCATION, 2017, 37:3, 454-468), which has been published in final form at http://dx.doi.org/10.1111\%2Fjade.12140. This article may be used for non-commercial purposes in accordance with Wiley Terms and Conditions for Use of Self-Archived Versions
} 
required students to use their design practice to research and critique the role of visual communication and photo-based images in perpetuating forms of stereotypical cultural representation. The eighteen students who participated worked in groups of three or four to design 'guerrilla educational campaigns' to communicate their findings to a wider audience. In this article we will discuss the rationale for choosing this topic, outline the rationale behind and structure of the workshop and reflect upon the learning experiences of the students to demonstrate that using their design practice is an effective way to introduce them to important cultural and critical theory.

\section{Methodology}

In reporting upon these projects we have positioned our work as an ethnographic-inductive phenomenological inquiry. Kellehear $(1993,21)$ argues that such inquiries seek 'to understand the commonsense meanings and experiences of the participants' in the research. Typically, ethnographic field-work uses methods such as direct observation of participants, interviews, field notes and the analysis of material culture (Kellehear 1993, 23). The ethnographic dimension of our research is encompassed in:

- our observation of student learning in action whilst creating various visual artefacts;

- the formal student presentations of those visual artefacts, at predetermined intervals, to communicate what they had learned;

- our informal conversations with students during their learning in action;

- our formal conversations with students during their formal presentations;

- our assessment notes taken at those presentations;

- the anonymous survey students completed at the end of the workshop to reflect upon their learning experiences in it.

Inductive research is 'sometimes referred to as grounded theory' (Kellehear 1993, 21). Grounded theory entails collecting, analysing and interpreting 'data to build middle-range theoretical frameworks' that inform and refine the theoretical analysis (Charmaz 2003, 249-50). The inductive dimension of our research is encompassed in collecting, analysing and interpreting the data in the forms outlined above in a manner that helped us to refine our understanding of how design students prefer to engage with critical theory. Phenomenological research seeks to understand the research participants' point of view and experience of particular phenomena and as such is both subjective and interpretative (Kellehear 1993, 27). Our research is phenomenological because it seeks to understand the learning experiences of the workshop participants. However as the analysis in this article is based upon our observation and interpretation of student presentations, documented process work, submitted final outcomes, our assessment notes and conversations about work in progress, our experience as educators and researchers is primary in this phenomenology. Consequently, this research is also heuristic because the reports of 'heuristic researchers are filled with the discoveries, personal insights, and reflections of the researchers' (Patton 2002, 107). Finally, we describe the research as a retrospective naturalistic inquiry because it studied real-life situations as they unfolded and we only undertook formal analysis of the documented work and our observations and notes retrospectively. In keeping with this, and given the limits of space, we will restrict our analysis to one or two projects that were indicative of the work produced and the learning experiences of the majority of the students. 


\section{The overproduction of images}

The explosion of imaging technologies and their application in the latter half of the twentieth century signals a re-emergent visual epistemology. Stafford (1997) argues that such an epistemology existed at other times in human history but was overwritten by the privileged position of the written word in empirical science and positivism, while Rorty (1967) characterises this preoccupation with the relationship between language and epistemology as the linguistic turn. Mitchell $(1995,11)$ argues that in the linguistic turn 'semiotics, rhetoric, and various models of "textuality" have become the lingua franca for critical reflections on the arts, the media, and cultural forms'. Like Stafford, Mitchell $(1995,11)$ notes an epistemological shift from the word to the image, that he calls the pictorial turn, because increasingly 'pictures form a point of peculiar friction and discomfort across a broad range of intellectual inquiry'. Visual communication design students are caught up in this friction. They are being educated to work in media that privilege a visual epistemology, which is more aligned to their learning preferences, yet the institutions they are learning in and the theory that critiques those media still promulgate, by and large, the primacy of the written word. Before we examine the learning preferences of design students, and how this can be used to get them to develop a critical approach to their practice, we need first to understand the nature of the pictorial turn and the visual landscape they will be working in and contributing to.

Media theorists, such as McLuhan (1964), Flusser 2007 ([1983]) and Baudrillard (1988) note that the images that dominated the visual landscape of the twentieth century were photo-based - still photographs, motion pictures or videos. Therefore the visual epistemology that has emerged through the pictorial turn is largely premised on photo-based images. These images - along with other messages, signs and artefacts - circulate in a cultural space Lotman (2005) calls the semiosphere. Volli (2000) argues that, like the biosphere, the semiosphere is subject to evolution and transformation, involution and stiffening. Manzini $(1992,8)$ argues that the semiosphere is one part of the complex environment of the human made world, the totality of which he calls the 'ecology of the artificial'. He argues that in it we have a 'system of production that is strongly geared to the ever accelerating production of worthless goods' (Manzini 1992, 8). We now live in an age where the rate at which we produce and disseminate images exceeds our capacity to view, let alone comprehend, more than the smallest percentage of them; thus the semiosphere is inflated by an overproduction of messages and images that, responding to the logic of consumption, are losing their intelligibility. The resultant 'semiotic pollution' (Manzini 1992, 7) that has accompanied this indicates to us that the system of reproduction is now geared towards the ever-increasing reproduction of worthless images. Such images are worthless in that we take them for granted because of their ubiquity. Simultaneously, their ideological underpinnings are concealed through this ubiquity. While we may consider ubiquitous images as worthless, it is wrong to assume they are not powerful.

The paradox of worthless images being powerful has a number of consequences. Firstly, as Smargiassi (2012) argues, the overproduction of images means that we are overwhelmed by an iconogenic surplus. This surplus is incongruent with the image's ability to create differences and oppositions because it is not content oriented as Volli (2008) argues. It promotes an imaginative space seemingly detached from the reality we observe and experience. Finally, this surplus transforms the audience into a tabula rasa, sensitive and receptive to media communication, but largely unaware of content beyond the moments of transmission and reception. This encourages 
communication in which 'making and unmaking according to the momentary self-interest' (Perniola 2004, 108) stages a substitute reality that serves the economic interests and political consensus of those commissioning the communication. Such a substitute reality is linked to the persistence of image stereotypes that, according to Zingale (2012), is a 'connotation ideologically oriented' that creates arbitrary simplifications and semantic stiffening. Tajfel (2001) argues that the essential cognitive function of the stereotype is to systematise and simplify information from the social environment in order to make sense of a world that would otherwise be too complex and chaotic for effective action. It is little wonder then that in an era characterised by the overproduction of images stereotypes dominate, for they are a simple response to dealing with complexity. However, to accept them as a pragmatic response to complexity underestimates the profound impact they have upon how we see, experience, understand and - most importantly act within and upon the world.

Merleau-Ponty (1964) argues that visible images are not simply representations of the world and separate to our perception of it but part of the horizon of our embodied perception. Visible images are as much a part of the reality we perceive as the objects they purport to represent. This elevates the image's epistemological and ontological status to that of what is commonly called material reality. Therefore the visible image, as a part of the horizon of the broader reality we perceive, informs the imaginary that in turn results in further visible images that become part of the horizon of the broader reality that we perceive. Merleau-Ponty (2010, 53) calls this interdependent relationship the 'image sensitising itself'. Diprose $(2010,33)$ argues that the transformation 'of the lived world' in this manner 'is not an extraordinary event' but 'the dynamics of ordinary perception'. Where Volli argues that the overproduction of images creates an imaginative space detached from reality, we argue that as the visible image - no matter how ubiquitous or stereotypical it is - is a part of the landscape of our perception and thus shapes our understanding of reality, even if at times it contradicts our experience of the reality the visible image purports to show us.

The visual communication design industry is responsible for the overproduction of visible images that populates the commercial media landscape and plays a pivotal role in imagining and transforming the horizon of our perceived reality. These images are mainly photographic and more often than not stock photographs. This makes the stock photography industry 'a powerful force behind the culture of the image' and a 'principal site for the production and distribution of photographic images in culture as a whole' (Frosh 2001, 628). The reality depicted in stock photography 'is the optimized version of a common global reality' (Bruhn 2003, 374). In short, stereotype and cliché reign supreme, with the clichéd image having significant 'iconological currency' (Bruhn 2003, 373). The audience that these images are designed for do not determine this currency alone, rather it is determined by the complex network of actors responsible for the production and dissemination of such images within media communications. This network includes visual communication designers who, by imagining the kinds of images which consumers will respond to, assume the role of 'cultural mediators' in that determination (Frosh 2001, 634).

Like Merleau-Ponty, Benjamin notes that human perception and images have an intrinsic relationship, however Merleau-Ponty is dismissive of the photographic image's capacity to inform perceptual transformation. Benjamin, in contrast, argues that with the photograph there has been an 'adjustment of reality to the masses and of the masses to reality' and that this 'is a process of 
unlimited scope, as much for thinking as for perception' (Benjamin 1969 [1935], 4). This means that the dynamics of human perception are contingent in part upon the types of images we can create. Diprose $(2010,37-8)$ also contends that the photograph informs human perception but does so in a very specific way, arguing that 'realist photography' expresses the world 'by lifting the viewer above the lived world to the position that tends to sediment the significance of relations between things and the possible paths for living these relations allow'. We argue that a further sedimentation of the significance of relations and paths of living occurs through the overreliance of stereotypical image content. The ideological consequence of this is that we become increasingly constrained in how we imagine the world, and our relations to and within it, can be. This is the visual landscape that emerging visual communication designers are both a part of and contributing to and why we chose to get students to explore the relationship between visual communication and cultural stereotype. However, getting design students to explore the ideological underpinnings of their practice, when the critiques of those underpinnings exist mainly in critical and cultural theory, is a challenge.

\section{The production of critical practice}

Baule (2012) argues for a critical culture inside communication design and the development of what he calls 'communicative antibodies' to challenge the dominance of stereotype or prejudice in media communications. These antibodies are the actions that critical practitioners put into place - through their consideration of the content, language, technologies, design methodologies and media formats used in the communications they are designing - that extend beyond stereotype. Furthermore, he argues that by training communication designers to be critically aware of the power they wield, and respectful of others, they can spread their antibodies in all systems of communication design to promote a different culture. The analysis of ideology and the critical examination of cultural practices has long been the focus of critical theory, but has not often been explored in the teaching of design practice. The deconstructive attitude that emerged in critical literary theory during the 1960s found its way into art and design schools in the 1980s (de Duve 1994) and the concomitant issues of representation and identity became the mainstays of art and design theory courses, compounding a binary division between theory and practice.

The literature that has emerged in the past fifteen years that critiques the teaching of theory in art and design schools argues that there is a disconnect between the dominant learning styles of art and design students and the learning styles typically assumed in teaching theory. The literature describes such students' learning styles variously as being intuitive and emotional (Collinson 2005, 716-17); visual-spatial (Lockheart et al. 2004, 97; Yee 2012, 471); tacit and knowing (McCannon 2011, 133); aesthetic and knowing (Irwin 2003, 63); and using visual thinking (Blackler 2014; Edwards \& Woolf 2007, 55; Grow 1994). The literature demonstrates that for these students learning based on reading, writing and listening is less effective than learning based on looking, doing and making because visual spatial learners 'tend to think in pictures rather than words' (Yee 2012, 471). In the field of constructivist learning theory this is known as kinaesthetic or experiential learning. For kinasethetic learners, learning is more profound when it is connected to their concrete and embodied experience (Kolb 1984). Additionally, it is commonly recognised that abductive reasoning is privileged over deductive reasoning in the kinaesethtic approach that designers use (Kolko 2011; Lawson 2006 [1980]; Louridas 1999). Ramsden (2003, 39-61) argues that to facilitate deep learning 
experiences the learning styles and predispositions of students must be accommodated. With this in mind the student learning tasks reported upon in this article, although theoretically framed, were essentially research-based critical design projects that tapped into the predominantly kinaesthetic learning styles of design students.

\section{The workshop structure}

The workshop ran in a five-day intensive mode with a two-hour briefing session for all eighteen participants occurring one week prior to its commencement. The briefing session consisted of a semi-formal lecture, heavy on visual content, on the nature of image stereotypes and the role of the media in perpetuating them; the presentation of the project brief; and a tutorial session where these issues and the project brief were discussed. We acknowledged in the briefing session that as the media industry rapidly consumes emerging forms of representation, cultural stereotypes could not be eliminated, only transformed, and developing alternative cultural representations would simply lead to new stereotypes. We made it clear that this project was concerned with students as emerging media practitioners and cultural mediators, and the development of their critical insight into the role of media in co-opting cultural representation and perpetuating it in stereotypical form. The students' task therefore was not to design alternative representations of gender, race or sexuality and so on, but to use media to interrogate and critique the mechanisms through which stereotypes come into circulation. As such, students were to design a guerrilla communication campaign that made the role of the media, and the consumers of media, explicit in this process. In this regard the project is ideological and not a typical industry response to a client need or brief, nor was it conceived to solve a specific design problem. Yee $(2012,467)$ calls problem-solving design 'affirmative design' because it 'perpetuates the existing norms of societal expectations' and affirms the ideological status quo. On the other hand 'critical design challenges the norm by expressing alternative values and ideologies'. In this regard the project was a critical intervention into visual communication, much along the lines of the sorts of projects advocated by Dunne \& Raby (2001).

The project brief was shaped by four framing questions: (1) What do I know?; (2) What does someone else know?; (3) What do I know now?; and (4) What can I imagine? The students conducted research for questions 1 and 2 between the briefing session and the commencement of the workshop. Question 1 required students to document and reflect upon their current understanding and first-hand experience of stereotype using photo-observation, auto-ethnography and the visual analysis of existing media images they encountered in their daily environment. For Question 2 students examined a variety of research papers, documentaries and websites critiquing the role of communication media in perpetuating stereotypical representations as well as interviewing other

people about their understanding and experience of it. The findings from this process formed the response to Question 3 and the content of a twenty-minute audio-visual presentation to the class

on the first day of the workshop. The final question involved using the design project to communicate what the students had learned about stereotypes and the media, and these were presented on the final day of the workshop. Between the day one presentations and the day five presentations of the final projects the students had to develop and present work in progress every day. They had ten minutes to present this work using the predetermined formats as outlined in the overview of the workshop structure below. 
Monday

\begin{tabular}{ll}
\hline 10am $-1 \mathrm{pm}$ & Preliminary presentation of initial inquiry using Question 1 (What do I know?) and Question \\
$2 \mathrm{pm}-6 \mathrm{pm}$ & 2 (What does someone else know?). \\
Analysis and insight of initial inquiry using Question 3 (What do I know now?). Work the material \\
from answering Question 1 and Question 2 into an overview map. \\
OUTPUT & $\begin{array}{l}\text { s designed A2 map of your knowledge and experience of stereotype to date including a } \\
\text { summary statement. }\end{array}$ \\
\hline
\end{tabular}

Tuesday

\begin{tabular}{ll}
\hline $10 \mathrm{am}-1 \mathrm{pm}$ & Conduct research into effective viral marketing strategies and platforms. \\
$2 \mathrm{pm}-6 \mathrm{pm}$ & Develop a design proposition and rough sketches using Question 4 (What can I Imagine?) to \\
& storyboard your campaign. \\
OUTPUT & $1 \times \mathrm{A} 2$ design rough concept storyboard. \\
\hline
\end{tabular}

Wednesday

\begin{tabular}{ll}
\hline $10 \mathrm{am}-1 \mathrm{pm}$ & Shoot in photographic lab if required. \\
$2 \mathrm{pm}-6 \mathrm{pm}$ & Revision of work in progress. \\
OUTPUT & $1 \times$ A2 rough design work in progress board.
\end{tabular}

Thursday

\begin{tabular}{ll}
\hline 10am $-1 \mathrm{pm}$ & Refinement and revision of work in progress. \\
& Shoot in photographic lab if required. \\
$2 \mathrm{pm}-6 \mathrm{pm}$ & Refinement of project concept and output in prototype form. \\
OUTPUT & $1 \times$ schematics or design prototypes.
\end{tabular}

Friday

$10 \mathrm{am}-1 \mathrm{pm}$

$2 \mathrm{pm}-6 \mathrm{pm}$

Finalisation and implementation of design outcome / proposal.

OUTPUT

Presentation of final work.

$1 \times$ A2 summary poster of project (including title, 250 word summary

and representative image of project).

$1 \mathrm{x}$ storyboard or schematic of project research and concept.

$1 \times$ viral information campaign.

\section{What students learned about stereotypes and the overproduction of images}

Our analysis of student learning is based upon our observation and interpretation of the student presentations, the documented process work and submitted final outcomes - as outlined above as well as our assessment notes and the reflection in action style conversations as per the case studies in Schön (1983) we had with students about their work in progress. During the work in progress presentations we made feedback notes about the relationship between what students had researched and the insights they derived from it in order to provide them with guidance in responding to Question 4. This feedback not only reinforced the transformation of the students' 
knowledge of the topic from tacit to explicit, it simultaneously made the tacit embodied experience of conducting research explicit.

For example, Student 1 (PZ) took photographs and made notes of the media images of women she encountered during a 24-hour period to answer Question 1. Her entry for 3.20pm includes Figure 1 and reads 'I'm in Piazza Duomo. I stop at a newsstand to buy a magazine. On covers I see only beautiful young women.' Her $4.15 \mathrm{pm}$ includes Figure 2, the billboard portrayal of women in the same precinct 'In most cases, it's always sensual or provocative.' As part of her research for Question 2 she found the site Zerostereotipi.it which attempts to highlight the complexity of the issues around the representation of women and cited the following 'Women's body, even if undressed,... is not something to be ashamed of or to censor' but 'exploiting the body of a woman (or worse a part of it) and use to sell is always questionable'. The point she made in doing so was that questioning such images of women was not a form of moral prudishness, rather it was about the context in which images of the female body were being used and that, as far as commercial media goes, images of women are largely sexualised. Finally she stated that 'as a communicator, I think to be the least conditioned person from stereotypes, because I have a very critical vision of the things around me', but despite this she noted 'I am surprised to realize how we are bombarded by stereotypes.' What her presentation revealed to us is that, firstly, even a self-aware media practitioner becomes immune to the volume of stereotypical images we are inundated with and, secondly, that through the conscious act of observing and documenting this over a 24-hour period she understood this more clearly than she had through any of the 'theoretical' literature she had been exposed to on the topic.

Student $2(G L)$, on the other hand, conducted interviews with two female creative professionals in response to Question 2. She was curious to understand what their experience and understanding of stereotype was. Her first interview subject, an art director, admitted that she adopted the persona of 'the creative stereotype' because she found it 'quite comforting, especially at work'. Her second interview subject, a studio manager, stated that 'few people are aware of using so many stereotypes every day to analyse the world and it is the same for being analysed by the other people'. From this first-hand experience she understood that stereotypes were a kind of role or guise

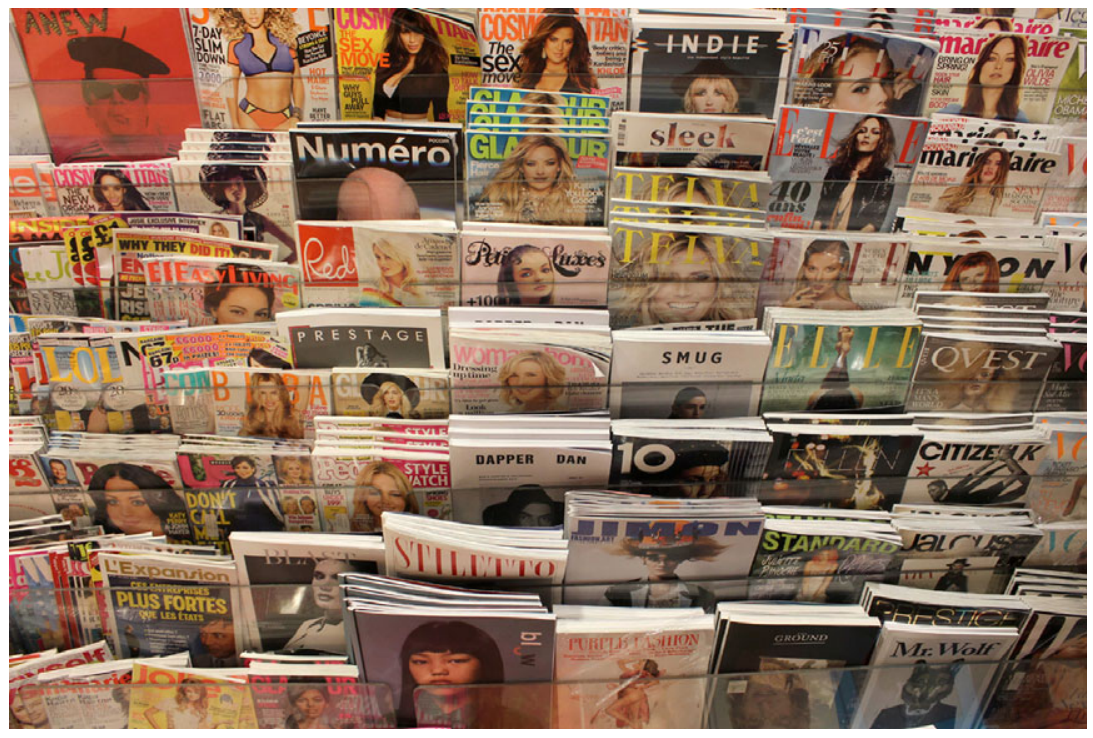

Figure 1. Photo-observation of newsstand. 


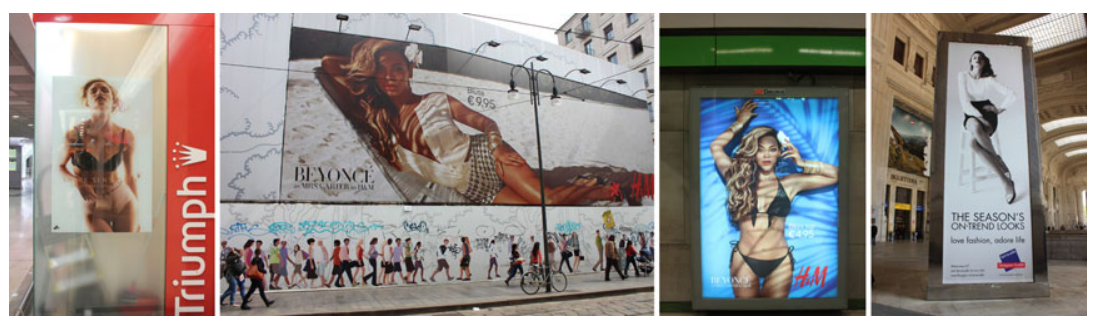

Figure 2. Photo-observation of billboards.

that people adopted for comfort and security as well as locating people in certain social groups. In turn she connected these insights to some of the research literature - specifically that concerning the 'stereotype content model' (this student cited Cuddy et al. 2008) - that examines the role of stereotype in in-group harmony. In her presentation on day one of the workshop this student noted that 'stereotyping is a problem solving action that enables us to predict behavioural tendencies'. On reflecting upon what she had learned from this exercise, she noted she 'was pretty surprised by the amount of stereotypes I apply in my daily life to judge other people and situations'. In our post-presentation conversation she noted that the interviews gave her a better understanding of the literature because she could see what it meant in real life and that in turn she used that to reflect upon her own use of them.

Similarly student 3 (NA) conducted interviews with 10 young adults, asking them about their personal experience and understanding of stereotypes. All interviewees freely admitted that they judged and classified people based upon appearance and mannerisms and recognised that this was a form of stereotyping and that it was a limiting process. For example, one interviewee defined stereotyping as when a person 'connects a really strict definition to one word and refuses to redefine what they think of as being that word'. All interviewees were conscious that they in turn were judged in similar terms. This student noted in their day one presentation that they were now more conscious of the extent to which stereotyping appears to be a normal pattern of human behaviour despite being aware that the literature on the topic indicated this.

The insights these three students derived from responding to Questions 1-3 were typical of the group as a whole. They point to the importance of the kinaesthetic dimension of learning through first-hand embodied experience of observation and conversation that brings to life the largely abstract experience of reading about a topic. The students' surprise at the extent to which they are 'bombarded by stereotypes' despite having a 'critical vision' is indicative of the moment that their tacit knowledge of this topic becomes explicit as a result of their kinaesthetic learning.

Questions 1 and 2 are pivotal in transforming tacit knowledge about the topic into the explicit knowledge required in Question 3. Question 4 reinforces this transformation through the communication of that knowledge, in designed form, in a manner that again leverages the students' predisposition to kinaesthetic learning. The project You Are Not A Label (Figure 3) involved a series of lifesized semi-transparent photographs of faceless stereotypical gendered images with the common phrase 'I am not' followed by a noun naming a stereotype typically associated with the image, such as 'stupid'. As they were designed to be stuck onto glass in public places - e.g. train doors, bus shelters and building entrances - people could insert their face into the picture and see themselves labelled with a particular stereotypical identity.

In a similar vein the Mirror on the Wall (Figure 4) project used the strategy of reflection to highlight the same concerns. The students designed large-scale magazine covers that had a reflective 

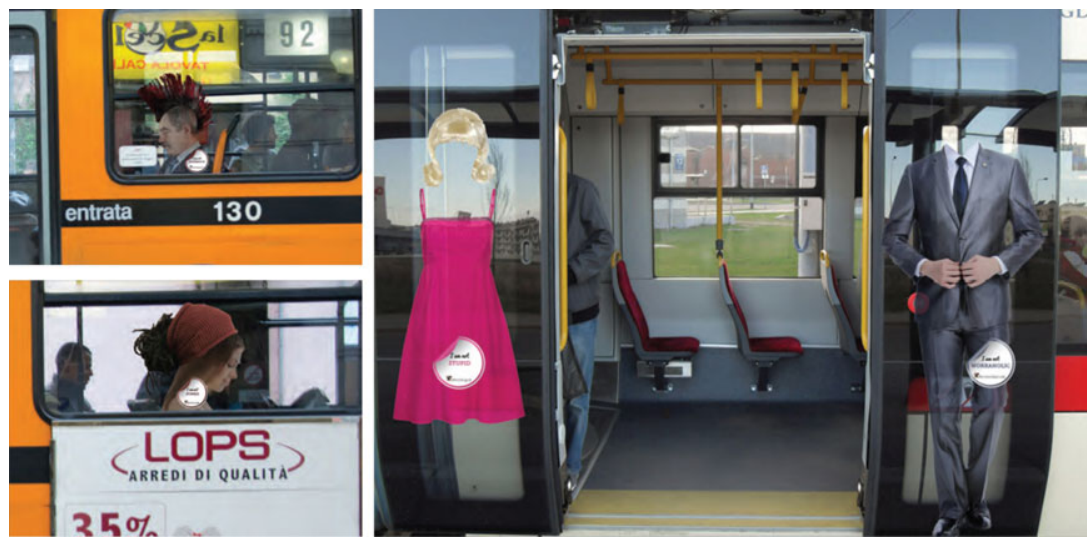

Figure 3. I am not a label.
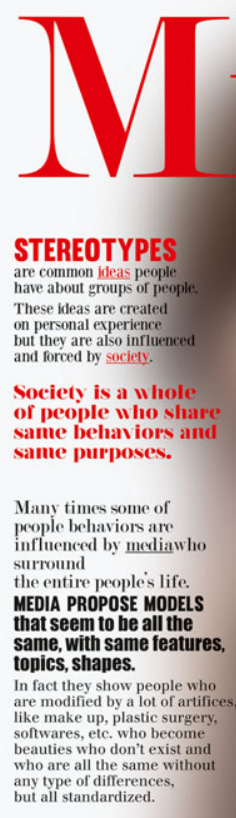

MEDIA ARE LIKE BOXES WHO PRODUCT A SERIAL
MANUFACTURE OF PEOPLE. But people they propose are not

Media distort the image of the reality and because of that common people feel thenselves the differences of everu person seem to have to disappear.
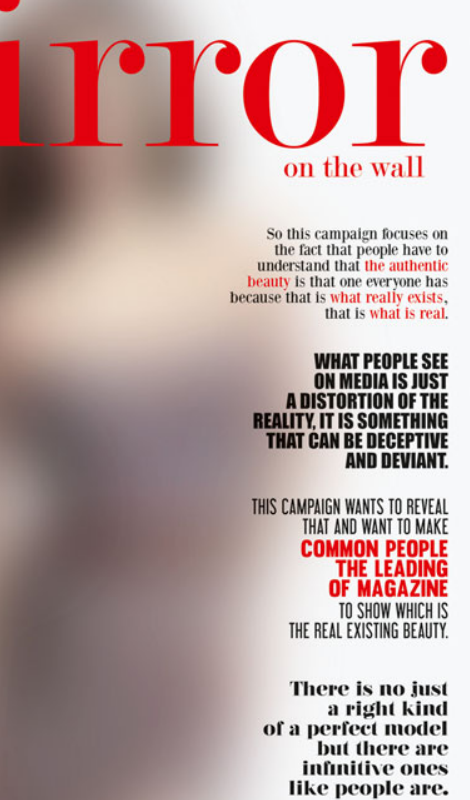

Figure 4. Mirror mirror.

surface, where the main image is normally placed, and all of the cover line copy contained research facts and commentary on stereotyping. These were designed to be located in public spaces where you would normally expect to find display advertisements promoting the latest issue of popular magazines. As people walked past them they were reflected on the surface of the ad, thus appearing to be on the magazine cover.

Perhaps the most ambitious project was the Towers of Babel (Figures 5 \& 6). The project team took audience interaction one step further than any other project by designing a campaign that encouraged audience members to shoot and upload short videos where they discussed their own 
Storyboard for TV

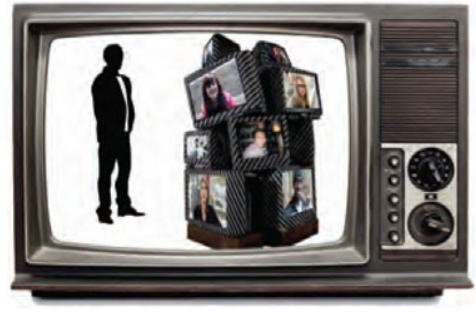

notice a new interactive bunch of TV's

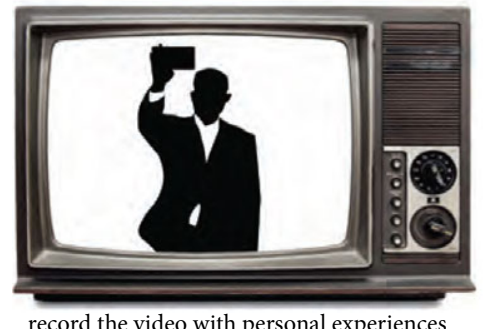

record the video with personal experiences

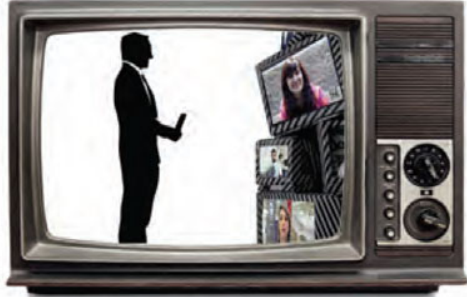

connect to "Tower of Bable" app by QR code

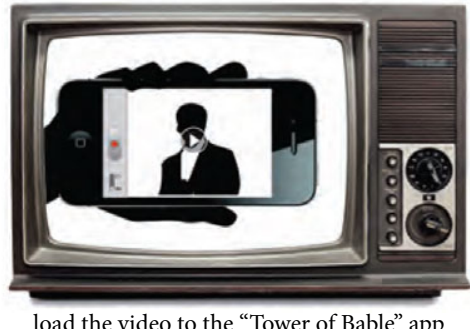

load the video to the "Tower of Bable" app

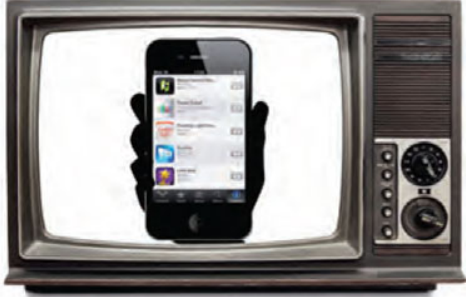

download “Tower of Bable” app

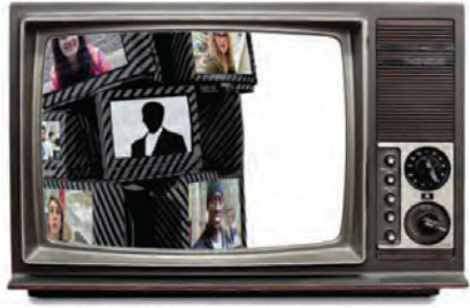

you can see the video uploaded by the app

Figure 5. Towers of Babel storyboard for TV.

Storyboard for Mobile Application

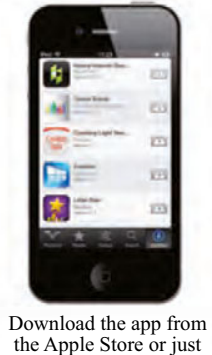

get the QR code
gR

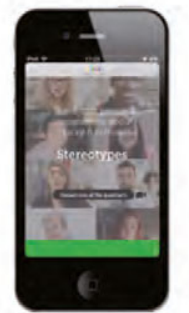

What is it about?
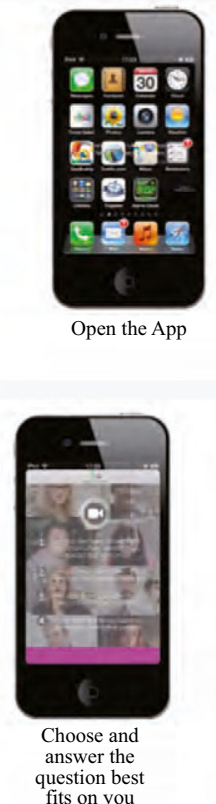

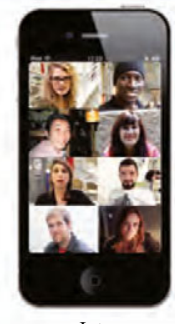

Intro

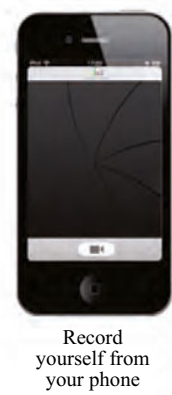

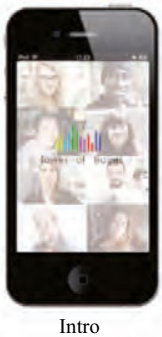
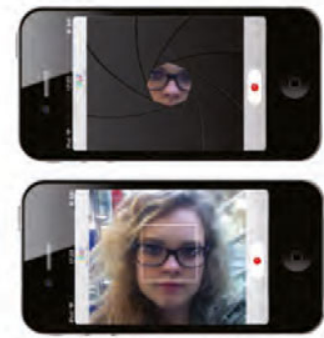

Record yourself from your phone and share
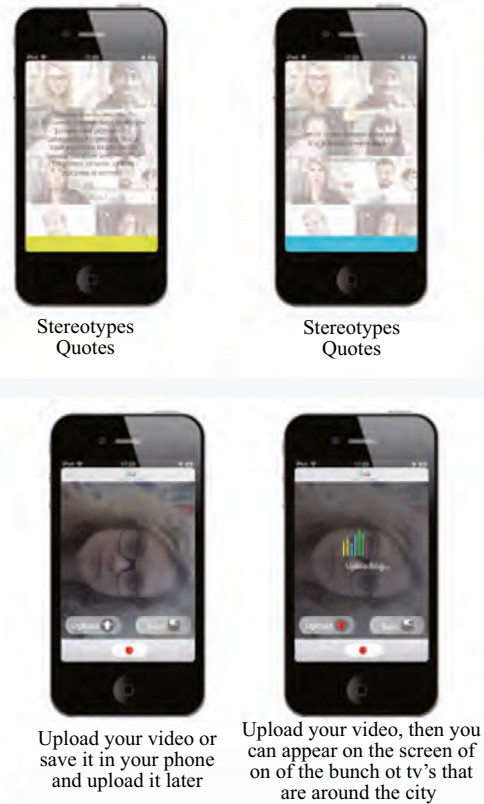

Figure 6. Towers of Babel storyboard for mobile application.

experiences of being stereotyped. In this way audience involvement was less constrained by the project concept and involved co-design of content. The students designed a purpose-built website that briefed members of the public on what the project was about and how they could participate. The website also served as a platform for the public to upload and share their videos, thus its content was user generated. However, more significantly, from a guerrilla campaign perspective, these videos were to be screened simultaneously on towers of television sets to be installed in public locations throughout Milan. Apart from being a clever means of displaying the work to the general 
public, and alerting them to the web side of the campaign, the use of the television screens was strategic in that the work was simultaneously critiquing the role of televisual and screen-based media in perpetuating stereotypes.

These projects embody, in a designed form, the explicit knowledge the students gained from their research that the perpetuation of stereotypes in images is as dependent on consumers of images as it is producers. You Are Not A Label and Mirror on the Wall did this by enabling passers-by to appear in the image and have a simulated experience of being labelled in a particular way. Towers of Babel took this one step further by allowing the audience to comment directly about being stereotyped and sharing that experience with others. Importantly, all these projects cleverly parallel the students' own kinaesthetic experience of learning about the mechanisms of stereotyping by designing platforms that themselves encouraged the kinaesthetic learning of this topic by the audience.

\section{What did we learn?}

In critiquing the dominant visual image - the photograph - used in modern media communication, Flusser (2007 [1984]) argues that as photography is the product of conceptual, as opposed to imaginative thought, and is shaped by analytical and instrumental paradigms then it is futile to challenge the self-replicating ideology underpinning it through critical theory, itself the product of conceptual thought. Rather, the best way to challenge the constraining dimension the photograph has on our imaginative capacity is through critical practice. As stereotypical representation more often than not comes in some form of photographic-based image, then the constraining dimension, or sedimentation of lived experience, of the photograph and the stereotype is amplified into our lived reality. This in turn affects how we imagine any alternate reality.

The goal of the workshop was to help develop in students a theoretically informed critical and imaginative approach to their design practice and expose them to the ideological power they wield as cultural mediators in the generation of visual images. In recognising that design students privilege kinaesthetic learning over conventional academic approaches to learning we drew on Kolb's (1984) concept of embodied learning - learning through feeling and doing - to encourage the next generation of designers to grow 'antibodies' to the dominant ideologies of contemporary media and develop a critical practice. In turn, this enabled campaigns to be developed that had the potential for audiences to develop their own critique of individual and societal attitudes towards stereotype and understand the role of the media in this but, more importantly, provide a less constrained imaginative space to imagine the kind of world we want.

Throughout the conduct of the workshop there was an ongoing dialogue with the students about the manner in which they were learning about theories of stereotype through both formal literature on the topic and first-hand research and design inquiry and practice. Although these conversations may be considered anecdotal, in keeping with a grounded theory - or indeed action research approach - they informed the advice we gave to students about where to take their research and design proposal as well as informed our understanding of the effectiveness of the learning structure of the workshops itself. During the conversations it was often noted by the students that although they found the approach we had developed to learning about theories of stereotype and representation challenging they also found it worthwhile. At the end of the workshop these students were asked to complete a simple open survey reflecting upon the positive and negative aspects of the learning experience in the workshops. Eight of the eighteen students 
completed the survey. Although none explicitly commented on the specifics of kinaesthetic learning, a term never discussed with them anyway, seven of the eight students that responded described their experience in the workshops in positive terms. For example:

\section{I liked the topic}

For me it was the best workshop, it was an experience more interesting than any l've done at XXXX.

It allowed us to compare different realities.

I'd like to have more workshops like this that invites you to think about personal experiences. You can learn a lot of things about others.

It was interesting, stimulating and flexible.

The content of the workshop was very interesting because it gave us the possibility to deepen an understanding of stereotype that is rarely investigated.

It was open and flexible, and because of that it can help us expand our horizons.

Although this is not a direct commentary on the kinaesthetic approach to learning framed within the workshops, we contend that had this learning approach failed such comments would not have been forthcoming. We argue, therefore, that each of these comments, in their own way, endorses the proposition that taking a kinaesthetic approach to learning complex theoretical issues through the implementation of a critical design practice resonated with these students. This in turn endorses our proposition at the outset of this article that in order to develop a critical approach to design practice, that necessarily requires an engagement with critical theory, then learning approaches aligned to the primarily kinaesthetic and visual learning styles of design students will be most efficacious.

Obviously the projects presented are the exemplary ones and a number were less successful in opening up a dialogue with their intended audience about the issues. Indeed some of them came close to perpetuating existing stereotypical forms, or ran the risk of creating new ones. Given the capacity of visual communication media to self-replicate, and given the reality that not all design students or designers are creatively and conceptually equal, this was inevitable. However, rather than this being seen as a failure on the part of less successful student projects, or the conception of the workshop itself, it was generally acknowledged by all participants in a post-workshop discussion that it pointed to the insidious and persistent nature of stereotype and the extent to which photo-based images help perpetuate them. It also pointed to the fact that we as social beings participate with varying degrees of agency, awareness and ethical intent in the perpetuation of existing and creation of new stereotypes. That the roles of the designer and the audience in this were revealed and acknowledged by all participants demonstrated to us as researchers that the theoretical objectives of the workshops had been effectively met that is, we had leveraged the students' preference for kinaesthetic learning and abductive reasoning to develop an awareness of a very real issue, and its attendant theories, through their practice. 
Mark Roxburgh is an Associate Professor of Design, University of Newcastle, New South Wales, Australia. His research interests cover design research, visual communication theory and practice, photographic theory and practice, and user experience design. His $\mathrm{PhD}$ explored the central role that visual images and visual perception play in design, with a specific emphasis on how photographic images condition us to perceive, experience and transform the world in a self-replicating manner. His ongoing research pursuits have been developing a phenomenological theory of photography to counter the dominance of critical theory and semiotic deconstruction, and developing a theory of design as a form of embodied perceptual synthesis to counter the dominance of the design problem solving metaphor. Contact Address: University of Newcastle, Design, Communication and Information Technology, University Drive, Callaghan, New South Wales 2308, Australia. Email: mark.roxburgh@newcastle.edu.au

Elena Caratti is an Assistant Professor at the Design Department, Politecnico di Milano, Milan, Italy. She teaches Visual Cultures in the degree course in Communication Design at the Design School. She is an architect, with a Master's in E-Design and a PhD in Industrial Design and Multimedia Communication (Politecnico di Milano). Her research activities are mainly concerned with basic design and visual cultures, with a particular interest in gender design. She has conducted workshops and seminars in Italy and abroad. website: www.dc xcg.org Contact address: Politecnico di Milano, Department of Design, Via Giovanni Durando, 38/A, Milan 20158, Italy. Email: elena.caratti@polimi.it

\section{References}

Baudrillard, J. (1988) Simulacra and simulations, in M. Poster [Ed.] Jean Baudrillard: Selected Writings. Stanford, CA: Stanford University Press, pp. 166-84.

Baule, G. (2012) Trasfigurazioni di genere. Immagini forti, immagini fragili: il design della comunicazione [Gender transfigurations. Powerful images, fragile images: the design of communication], in G. Baule \& V. Bucchetti [Eds] Anticorpi comunicativi [Communicative antibodies]. Milan: Franco Angeli. pp. 69-73.

Bellino, F. (2010) Per un'etica della comunicazione [For an ethics of communication]. Milan: Bruno Mondadori.

Benjamin, W. (1969 [1935]) The work of art in the age of mechanical reproduction, in H. Arendt [Ed.] Illuminations. New York: Schocken Books, pp. 1-26.

Blackler, A. (2014) Using a visually-based assignment to reinforce and assess design history knowledge and understanding, in Y. Lim \& K. Niedderer [Eds] Design Big Debates: Pushing the Boundaries of Design Research. Umea, Sweden: Umea Institute of Design, Umea University, pp. 1244-59.

Bruhn, M. (2003) Visualization services: stock photography and the picture industry, Genre, Vol. 36, No. 3-4, pp. 365-82.

Charmaz, K. (2003) Grounded theory: objectivist and constructivist methods, in N. K. Denzin \& Y. S. Lincoln [Eds] Strategies of Qualitative Inquiry. London: Sage, pp. 249-91.

Collinson, J. A. (2005) Artistry and analysis: student experiences of UK practice-based doctorates in art and design, International Journal of Qualitative Studies in Education, Vol. 18, No. 6, pp. 713-28.

Cuddy, A., Fiske, T. \& Glick, P. (2008) Warmth and competence as universal dimensions of social perception: the stereotype content model and the BIAS map, Advances in Experimental Social Psychology, Vol. 40, pp. 61-149.

De Duve, T. (1994) When form has become attitude - and beyond, in N. De Ville \& S. C. Foster [Eds] The Artist and the Academy: Issues in Fine Art Education and the Wider Cultural Context. Southampton: John Hansard Gallery, pp. 23-40.

Diprose, R. (2010) In light relief the image sensitises itself: on the ontology, ethics and politics of photography in design research, in M. Roxburgh [Ed.] Light Relief (Part II). Sydney: DAB DOCS, pp. 33-47.

Dunne, A. \& Raby, F. (2001) Design Noir: The Secret Life of Electronic Objects. London and Basel: Autumn Media and Birkhasuer.

Edwards, H. \& Woolf, N. (2007) Design research by practice: modes of writing in a recent PhD from the RCA, Journal of Writing in Creative Practice, Vol. 1, No. 1, pp. 53-67.

Flusser, V. (2007 [1983]) Towards a Philosophy of Photography. London: Reaktion Books. 
Frosh, P. (2001) Inside the image factory: stock photography and cultural production, Media, Culture \& Society, Vol. 23, No. 5, pp. 621-46.

Grow, G. (1994) The writing problems of visual thinkers, Visible Language, Vol. 28, No. 2, pp. 134-61.

Irwin, R. (2003) Toward an aesthetic of unfolding in/sights through curriculum, Journal of the Canadian Association of Curriculum Studies, Vol. 1, No. 2, pp. 63-78.

Kellehear, A. (1993) The Unobtrusive Researcher: A Guide to Methods. St Leonards, NSW: Allen \& Unwin.

Kolb, D. A. (1984) Experiential Learning: Experience as the Source of Learning and Development. New Saddle River, NJ: Prentice Hall.

Kolko, J. (2011) Exposing the Magic of Design: A Practitioner's Guide to the Methods and Theory of Synthesis. Oxford: Oxford University Press.

Lawson, B. (2006 [1980]) How Designers Think: The Design Process Demystified. Oxford: Architectural Press.

Lockheart, J., Edwards, H., Raein, M. et al. (2004) Writing purposefully in art and design (writing pad), Art, Design and Communication in Higher Education, Vol. 3, No. 2, pp. 89-102.

Lotman, Y. M. (2005) On the Semiosphere, Sign Systems Studies, Vol. 33, No. 1, pp. 205-29.

Louridas, P. (1999) Design as bricolage: anthropology meets design thinking, Design Studies, Vol. 20, No. 6, pp. 517-35.

Manzini, E. (1992) Prometheus of the everyday: the ecology of the artificial and the designer's responsibility, Design Issues, Vol. 9, No. 1, pp. 5-20.

McLuhan, M. (1964) Understanding Media: The Extensions of Man. London: Routledge \& Kegan Paul.

Merleau-Ponty, M. (1964) The Primacy of Perception, and Other Essays on Phenomenological Psychology, the Philosophy of Art, History, and Politics. Evanston, IL: Northwestern University Press.

Merleau-Ponty, M. (2010) Institution in Personal and Public History and the Problem of Passivity: Sleep, the Unconscious, Memory. Course Notes at the Collège de France (1954-55). Evanston, IL: Northwestern University Press.

Mitchell, W. J. T. (1995) Picture Theory: Essays on Verbal and Visual Representation. Chicago, IL: University of Chicago Press.

Patton, M. Q. (2002) Qualitative Research \& Evaluation Methods. Thousand Oaks, CA: Sage.

Perniola, M. (2004) Contro la comunicazione [Against communication].Turin: Einaudi.

Ramsden, P. (2003) Learning to Teach in Higher Education. London: Routledge Falmer.

Rorty, R. [Ed.] (1967) The Linguistic Turn: Recent Essays in Philosophical Method. Chicago, IL: University of Chicago Press.

Schön, D. A. (1983) The Reflective Practitioner: How Professionals Think in Action. New York: Basic Books.

Smargiassi, M. (2012) L'inciviltà delle immagini [The incivility of the images] (online blog, 12 December). Available at: http://smargiassi-michele.blogautore.repubblica.it/2012/12/12/lincivilta-delle- immagini/ (accessed 3 April 2017).

Stafford, B. M. (1997) Good Looking: Essays on the Virtue of Images. Cambridge, MA: MIT Press.

Tajfel, H. (2001) Social stereotypes in social groups, in M. A. Hogg \& D. Abrams [Eds] Intergroup Relations: Key Readings. Philadelphia, PA: Psychology Press, pp. 132-45.

Volli, U. (2000) Manuale di semiotica [Semiotic manual]. Bari and Rome: Laterza.

Volli, U. (2008) Semiotica della pubblicità [Semiotic of advertising]. Bari and Rome: Laterza.

Yee, J. (2012) Implications for research training and examination for design PhDs, in R. Andrews et al. [Eds] The SAGE Handbook of Digital Dissertations and Theses. London: Sage, pp. 461-92.

Zingale, S. (2012) Immobili Visioni. Domande intorno alla persistenza dello stereotipo [Static visions. Questions around the persistence of stereotype], in G. Baule \& V. Bucchetti [Eds] Anticorpi comunicativi [Communicative antibodies], Milan: Franco Angeli. 